\title{
Blending effect of rotor spun yarn with different blending methods
}

\author{
DOI: $10.35530 / 1 T .070 .05 .1580$
}

RUI HUA YANG

QIAN QIAN DENG

\section{ABSTRACT - REZUMAT}

\section{Blending effect of rotor spun yarn with different blending methods}

Color blended rotor spun yarn mixing with different methods were spun. Three blending methods were used, one passage of drawing, three passages of drawing and rovings during multi-channel spinning. Multi-channel spinning is modified on rotor spinning machine, which is implemented by a novel mechanical system specially designed to incorporate three separate feed rollers side by side and controlled by servo motors with PLC. Using this new method, blend ratio of yarn can be controlled and realized by asynchronous drafted rovings. 37 type of color blend yarn were produced with different blending ratios. And each yarn was intercepted with 5 cross sections and a total of 185 cross-sectional images were taken. Hamilton index of different colored fibers were calculated of the each type of yarns. And sum of absolute values of Hamilton index were got to demonstrated fibers blending effect in yarns cross sections. All the Hamilton index of the yarns prepared by the three above mentioned methods were all around 5, much below 20. The results showed that regardless of blending method used, the blending effects of rotor spun yarns were all very good.

Keywords: blended yarn, cotton fiber; Hamilton transfer index, uniformity, multi-channel spinning

\section{Efectul de amestecare al firului filat cu rotor prin diferite metode de amestecare}

Firele colorate în amestec au fost filate cu rotor prin diferite metode de filare. Au fost utilizate trei metode de amestecare, printr-un pasaj de etirare, prin trei pasaje de etirare și prin semitorturi în timpul filării cu canale multiple. Filarea cu canale multiple a fost modificată pe mașina de filat cu rotor, printr-un nou sistem mecanic special conceput pentru a încorpora trei cilindri de încărcare separți, unul lângă altul și controlați de servomotoare cu PLC. Folosind această nouă metodă, raportul de amestec dintre fire poate fi controlat și realizat prin semitorturi etirate asincrone. 37 de tipuri de fire colorate în amestec au fost realizate cu diferite tipuri de raport de amestec. Fiecare fir a fost analizat prin 5 secțiuni transversale și au fost prelevate în total 185 de imagini. A fost calculat indicele Hamilton al diferitelor fibre colorate pentru fiecare tip de fir. De asemenea, suma valorilor absolute ale indicelui Hamilton a fost obținută pentru efectul de amestecare a fibrelor, în secțiunile transversale ale firelor. Indicele Hamilton total al firelor realizate prin cele trei metode menționate mai sus a fost de aproximativ \pm 5 , mult sub \pm 20 . În concluzie, indiferent de metoda folosită, efectul de amestecare al firelor filate cu rotor înregistrează rezultate foarte bune.

\section{INTRODUCTION}

The color blended yarn has the characteristics both of fashion and environmental protection. The color of the fabric woven with the color blended yarn is natural and gentle, showing a strong three-dimensional feeling and being deeply loved by consumers. The production of mixed yarns has many varieties and can have small batches, and is very popular among small and medium-sized enterprises [1-3].

Combining the new spinning technology with the production of blended yarns and exploring more suitable production processes and methods are the development directions of color spinning.

The fiber blending process of the color blended yarns includes fiber blending, sliver blending and roving blending [4-6]. Multi-colored fiber blending is generally carried out in the open and cleaning process, and the blending effect is sufficient, but the process is complicated and the requirements of the fibers are stiff. The sliver blending is made in drawing process, and parameters are set according to the blending ratio and slivers linear densities. It has the advantage of high efficiency. And the cost of equipment cleaning is high for both of fiber blending and sliver blending. The roving blending is to feed two or three rovings of different colors to the spinning frame with different feeding speed separately according to the color blending ratio, achieving the desired color [3]. It shows spinning flexibility and products variety of the blended yarns. However, there is not any published work to reveal the fiber blending effect of sliver blending and roving blending.

In this study, cotton fibers of three colors (red, yellow and blue) were used as the raw material, and color blended rotor spun yarns were produced by the two above-mentioned methods respectively. The blending uniformity of the fibers in the yarn was analyzed.

\section{FIBER BLENDING METHODS}

\section{Sliver blending}

Sliver blending is realized by blending a plurality of colored slivers in the drawing process according to a pre-set color blending ratio. It can be used by one 
passage drawing or three passages, depending on the requirement of fiber blending effect. In this study, the blending effects of one passage drawing and three are both analyzed.

\section{Roving blending}

In this research, roving blending is made by threechannel rotor spinning process which is shown in figure 1. It is implemented by a novel mechanical system specially designed to incorporate three separate feed rollers side by side and controlled by servo motors with PLC. Using this new method, three different slivers can be fed and controlled individually (feeding speeds can be the same or different). So that various color blended yarns can be produced by controlling the ratio of three basic colored rovings (red, yellow and blue) via changing the feed speed of each roving, and also different materials blended yarns could be produced.

As observed, the three different colored fiber rovings are fed to the opening roller through their corresponding feeding rollers. Then the continuous and tight fiber strips are divided into sparse streams by splitting to achieve separation and orientation of the fibers. Under the acceleration airflow in the fiber transport channel, the streams are further separated into a single fiber to enter the rotor. Such single fibers are collected in the groove at the bottom of the rotor with the centrifugal force of the high-speed rotor. Accordingly, through stripping, opening, cleaning, carding, and transfer of the carding roller, fiber bundles are separated into single fibers. Afterwards, multiple slivers asynchronously feed into the rotor spun unit. Multi layers of condensed fibers are combined as a bundle and twisted to form a yarn by the blocking action of the false twisting disc, which is led by a mother yarn. Subsequently, the yarns are wound onto a tube by winding roller. With such a spinning process, the objective of flexibility, high efficiency, and high yield are realized.

\section{EXPERIMENTS}

Red, yellow and blue colored cotton rovings and slivers were used as the raw materials. Rovings linear densities of red, yellow and blue are 4.34, 4.4 and $4.26(\mathrm{~g} / 10 \mathrm{~m})$ respectively. And linear densities of slivers are 45.28, 43, 42.64 (g/10 m). Three blending methods were used, one passage of drawing, three passages of drawing and roving. Both of two and three component colored yarns were spun with linear density of 44.85 tex and twist factor of 400 with different blending ratios. The blending ratios of sliver blending and roving blending were showed in tables 1-2.

\begin{tabular}{|c|c|c|c|c|c|c|c|c|c|c|c|c|}
\hline \multicolumn{13}{|c|}{ BLENDING RATIO OF TWO-COMPONENT YARN BLENDED BY ONE PASSAGE OF DRAWING } \\
\hline \multicolumn{4}{|c|}{ One passage of drawing } & \multicolumn{4}{|c|}{ Three passage of drawing } & \multicolumn{5}{|c|}{ Roving during spinning process } \\
\hline \multirow[t]{2}{*}{ No. } & \multirow{2}{*}{$\begin{array}{c}\text { Sliver } \\
\text { number }\end{array}$} & \multicolumn{2}{|c|}{$\begin{array}{l}\text { Blending } \\
\text { ratios } \\
(\%)\end{array}$} & \multirow[t]{2}{*}{ No. } & \multirow{2}{*}{$\begin{array}{c}\begin{array}{c}\text { Sliver } \\
\text { number }\end{array} \\
\begin{array}{c}\text { Yellow: } \\
\text { Blue }\end{array}\end{array}$} & \multicolumn{2}{|c|}{$\begin{array}{l}\text { Blending } \\
\text { ratios } \\
(\%)\end{array}$} & \multirow[t]{2}{*}{ No. } & \multicolumn{2}{|c|}{$\begin{array}{c}\text { Blending } \\
\text { ratios } \\
(\%)\end{array}$} & \multicolumn{2}{|c|}{$\begin{array}{c}\text { Feed speed } \\
\text { of rovings } \\
\text { (m/min) }\end{array}$} \\
\hline & & Yellow & Blue & & & Yellow & Blue & & Yellow & Blue & Yellow & Blue \\
\hline 1 & $1: 5$ & 16.8 & 83.2 & 6 & $1: 5$ & 16.8 & 83.2 & 9 & 16.8 & 83.2 & 0.51 & 1.41 \\
\hline 2 & $2: 4$ & 33.5 & 66.5 & 7 & $2: 4$ & 33.5 & 66.5 & 10 & 33.5 & 66.5 & 1.03 & 2.10 \\
\hline 3 & $3: 3$ & 50.2 & 49.8 & 8 & $3: 3$ & 50.2 & 49.8 & 11 & 50.2 & 49.8 & 1.54 & 1.57 \\
\hline 4 & $4: 2$ & 66.8 & 33.2 & & & $\theta$ & & 12 & 66.9 & 33.1 & 2.04 & 1.05 \\
\hline 5 & $5: 1$ & 83.4 & 16.6 & & & 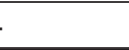 & & 13 & 83.5 & 16.5 & 2.55 & 0.52 \\
\hline
\end{tabular}

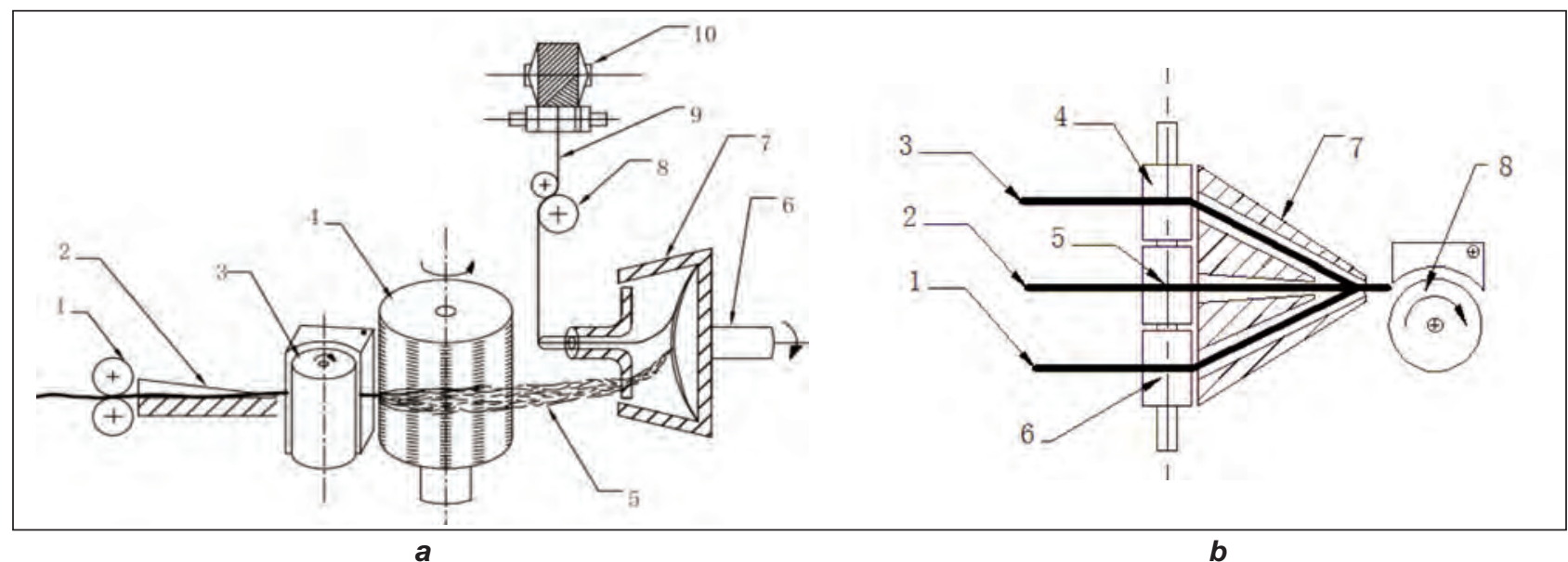

Fig. 1. Three channel rotor spun feed mechanism (a: 1 - combined feed rollers, 2 - collector, 3 - main roller, 4 - carding roller, 5 - fiber transport channel, 6 - bearing, 7 - rotor, 8 - guide roller, 9 - yarn, 10 - bobbin; $b: 1,2,3$ - slivers, 4, 5, 6 - combined feed rollers, 7 - collector, 8 - main roller) 


\begin{tabular}{|c|c|c|c|c|c|c|c|c|c|c|c|c|c|c|c|c|}
\hline \multicolumn{17}{|c|}{ BLENDING RATIO OF THREE-COMPONENT YARN BLENDED BY ONE PASSAGE OF DRAWING } \\
\hline \multicolumn{5}{|c|}{ One passage of drawing } & \multicolumn{5}{|c|}{ Three passage of drawing } & \multicolumn{7}{|c|}{ Roving during spinning process } \\
\hline \multirow{2}{*}{ No. } & \multirow{2}{*}{\begin{tabular}{|c|}
$\begin{array}{c}\text { Sliver } \\
\text { number }\end{array}$ \\
Red: \\
Yellow: \\
Blue
\end{tabular}} & \multicolumn{3}{|c|}{$\begin{array}{c}\text { Blending ratios } \\
(\%)\end{array}$} & \multirow{2}{*}{ No. } & \multirow{2}{*}{$\begin{array}{c}\begin{array}{c}\text { Sliver } \\
\text { number }\end{array} \\
\text { Red: } \\
\text { Yellow: } \\
\text { Blue }\end{array}$} & \multicolumn{3}{|c|}{$\begin{array}{l}\text { Blending ratios } \\
(\%)\end{array}$} & \multirow{2}{*}{ No. } & \multicolumn{3}{|c|}{$\begin{array}{l}\text { Blending ratios } \\
(\%)\end{array}$} & \multicolumn{3}{|c|}{$\begin{array}{c}\text { Feed speed of rov- } \\
\text { ings } \\
\text { (m/min) }\end{array}$} \\
\hline & & Red & Yellow & Blue & & & Red & Yellow & Blue & & Red & Yellow & Blue & Red & Yellow & Blue \\
\hline 14 & 1:1:4 & 16.9 & 16.4 & 66.7 & 24 & $1: 1: 4$ & 16.9 & 16.4 & 66.7 & 28 & 16.9 & 16.4 & 66.7 & 0.52 & 0.50 & 2.11 \\
\hline 15 & $1: 2: 3$ & 16.9 & 32.9 & 50.2 & 25 & $1: 2: 3$ & 16.9 & 32.9 & 50.2 & 29 & 17.0 & 32.8 & 50.2 & 0.53 & 1.00 & 1.59 \\
\hline 16 & 1:3:2 & 17.0 & 49.4 & 33.6 & 26 & 1:3:2 & 17.0 & 49.4 & 33.6 & 30 & 33.7 & 16.4 & 49.9 & 0.53 & 1.51 & 1.06 \\
\hline 17 & 1:4:1 & 17.1 & 66.1 & 16.8 & 27 & 1:4:1 & 17.1 & 66.1 & 16.8 & 31 & 33.8 & 32.8 & 33.4 & 0.53 & 2.02 & 0.53 \\
\hline 18 & 2:1:3 & 33.8 & 16.3 & 49.9 & & & - & & & 32 & 34.0 & 49.3 & 16.7 & 1.05 & 0.50 & 1.58 \\
\hline 19 & $2: 2: 2$ & 33.8 & 32.8 & 33.4 & & & - & & & 33 & 50.5 & 16.3 & 33.2 & 1.05 & 1.00 & 1.05 \\
\hline 20 & $2: 3 ; 1$ & 33.9 & 49.4 & 16.7 & & & - & & & 34 & 50.6 & 32.7 & 16.7 & 1.05 & 1.51 & 0.53 \\
\hline 21 & $3: 1: 2$ & 50.5 & 16.3 & 33.2 & & & - & & & 35 & 67.9 & 16.1 & 16.0 & 1.57 & 0.50 & 1.05 \\
\hline 22 & $3: 2: 1$ & 50.6 & 32.7 & 16.7 & & & - & & & 36 & 50.6 & 32.7 & 16.7 & 1.57 & 1.00 & 0.53 \\
\hline 23 & $4: 1: 1$ & 67.9 & 16.1 & 16.0 & & & - & & & 37 & 58.4 & 28.0 & 13.6 & 2.11 & 1.00 & 0.50 \\
\hline
\end{tabular}

\section{RESULTS AND DISCUSSION}

The Hamilton fiber migration index is a parameter to calculate and analyze the distribution of component fibers in a blended yarn [7-9]. It is based on certain first moments of the given component about the center of the yarn cross-section. Here, the maximum possible zoned fiber counts are taken on suitable number of cross-sections which expresses the actual migration of the component that could have occurred in the yarn. While $\pm 100 \%$ migration index value represents complete separation of the components but a zero value represents random distribution. The positive and negative signs denote outward and inward migration respectively [10-12].

Each yarn was intercepted with 5 cross sections and 185 cross-sectional images of 37 yarns were used to calculate the Hamilton index of the fibers in each cross section. And representative samples of each yarn were pointed out in figures $2-7$. The calculated mean valueswere showed in table 3.

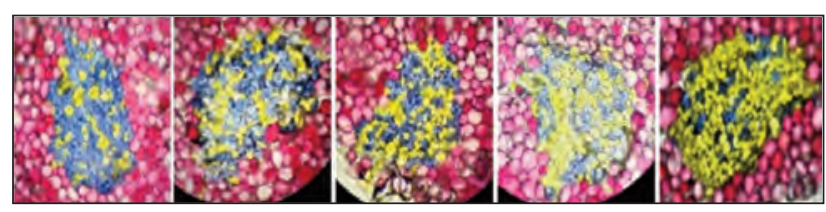

Fig. 2. Two-component yarn blended by one passage of drawing (1-5)

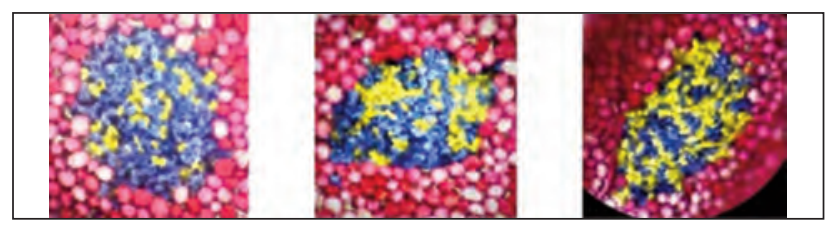

Fig. 3. Two-component yarn blended by three passage of drawing (6-7)

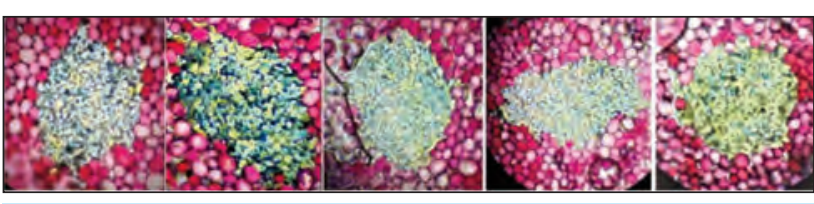

Fig. 4. Two-component yarn blended by rovings (9-13)

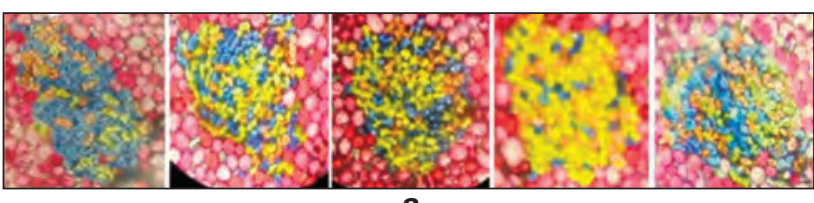

a

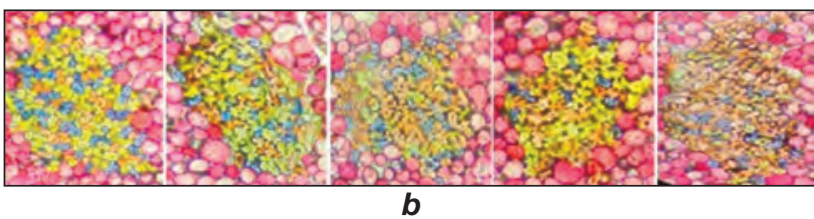

Fig. 5. Three-component yarn blended by one passage of drawing: $a-(14-18) ; b-(19-23)$

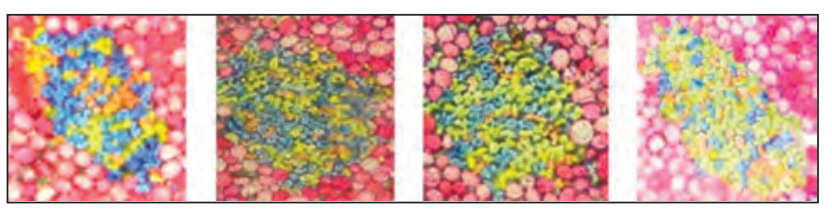

Fig. 6. Three-component yarn blended by three passages of drawing (24-27)

When one passage of sliver blending is used, the sum of the absolute values of the Hamilton index for each colored fiber was $1 \%$ and $3 \%$ for two-component and three-component yarns respectively.

For three passages, the sum of the absolute values of the Hamilton index was $2.34 \%$ and $5.03 \%$ for the two above mentioned yarns. 


\begin{tabular}{|c|c|c|c|c|c|c|c|}
\hline \multicolumn{8}{|c|}{ HAMILTON INDEX OF FIBERS } \\
\hline $\begin{array}{c}\text { Two } \\
\text { components }\end{array}$ & $\begin{array}{c}\text { One } \\
\text { passage } \\
(\%)\end{array}$ & $\begin{array}{c}\text { Three } \\
\text { passages } \\
(\%)\end{array}$ & $\begin{array}{c}\text { Rovings } \\
(\%)\end{array}$ & $\begin{array}{c}\text { Three } \\
\text { components }\end{array}$ & $\begin{array}{c}\text { One } \\
\text { passage } \\
(\%)\end{array}$ & $\begin{array}{c}\text { Three } \\
\text { passages } \\
(\%)\end{array}$ & $\begin{array}{c}\text { Rovings } \\
(\%)\end{array}$ \\
\hline Yellow fibers & 0.50 & 1.17 & -1.20 & Yellow fibers & -1.04 & 0.91 & 3.79 \\
\hline \multirow{2}{*}{ Blue fibers } & \multirow{2}{*}{-0.50} & \multirow{2}{*}{-1.17} & \multirow{2}{*}{1.20} & Blue fibers & 1.41 & 0.56 & 2.10 \\
\hline & & & & Red fibers & 0.55 & -3.56 & -1.29 \\
\hline $\begin{array}{c}\text { Sum of } \\
\text { absolute value }\end{array}$ & 1 & 2.34 & 2.4 & $\begin{array}{c}\text { Sum of } \\
\text { absolute value }\end{array}$ & 3 & 5.03 & 7.18 \\
\hline
\end{tabular}
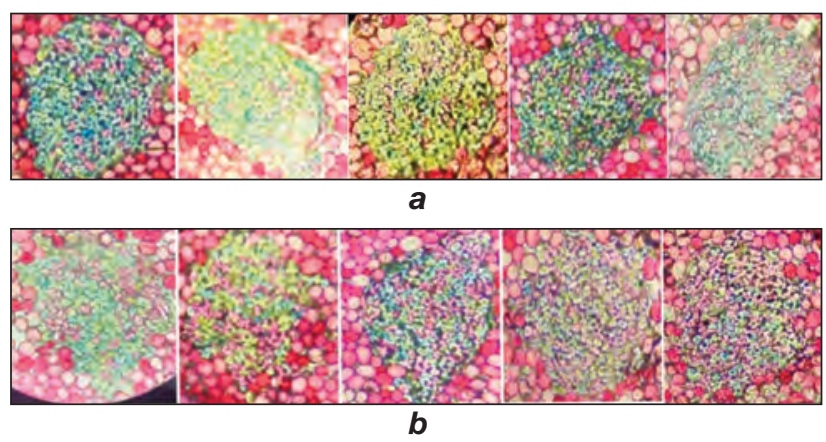

Fig. 7. Three-component yarn blended by rovings: $a-(28-32) ; b-(33-37)$

When the blending method is by roving, the sum of the absolute values of the Hamilton index was $2.4 \%$ and $7.18 \%$ for two-component and three-component yarns respectively.

It was figured out that the blending effect of one passage is the best, three passage second, and roving third. Compared with one passages, the blending effect of three passages was reduced because of the deviation of fiber movement distance during the drawing process.

During the rotor spun process, fiber strand was combed and mixed by the opening roller. Under the centrifugal force in the rotor, passing by transport channel, fibers were then mixed and condensed as a bundle in the rotor groove. Then the yarn was formed after being twisted. So there were three chances to mix fibers. That also means rotor spun yarn with sliver blending had been blended not only during the spinning process, but also during the drawing process. That's the reason why blending effect of blended rotor yarn with sliver blending was better than that of roving blending.
But all the Hamilton index values of three blending types were under $20 \%$, which demonstrated that the blending effects of the rotor spun yarns all met the blending uniformity requirements. Therefore, fibers can be very well blended during the rotor spun process, not matter which blending method was used.

\section{CONCLUSION}

Three methods of fibers blending, one passage drawing, three passages and roving were used to mix fibers. Two components and three components color blended rotor yarns were spun. Fiber blending effects of yarns were studied by Hamilton index. The results showed that the Hamilton index of fibers in yarn cross sections obtained by the three blending methods were all within the range of $\pm 5 \%$, less than $\pm 20 \%$, indicating that the blending method has no obvious influence on the uniformity of the rotor-spun blended yarn. And rotor spun is a good method to blend fibers during spinning process. The most suitable fiber blended method can be selected according to the actual situation to maximize the benefit of rotor spun yarns.

\section{ACKNOWLEDGEMENT}

This work was supported by Natural Science Foundation of Jiangsu Province of China No. BK20181350, the National Natural Science Foundation of China (No. 51403085), the National Key R\&D Program of China (2017YFB0309200), the Innovation fund project of Cooperation among Industries, Universities \& Research Institutes of Jiangsu Province (BY2016022-29), the Fundamental Research Funds for the Central Universities No. JUSRP51631A and Priority Academic Program Development of Jiangsu Higher Education Institutions (PAPD).

\section{REFERENCES}

[1] Ahmad, Z., Eldeeb, M., Iqbal, S., et al., Effect of yarn structure on cover factor in woven fabrics, In: Industria Textila, 2018, 69, 3, 197-201, http://doi.org/10.35530/IT.069.03.1416

[2] Seyedi, R., Najar, S.S., Hoseinpour, A.R., Investigation of fiber migration in rotor-jet spun yarn, In: Journal of the Textile Institute, 2017, 108, 10, 1794-1799

[3] Yang, R.H., Xue,Y., Gao, W.D., Airflow characteristics of different groove type during rotor spinning process, In: Industria Textila, 2017, 68, 3, 165-169, http://doi.org/10.35530/IT.068.03.1367 
[4] Karthik, T., Murugan, R., Sakthivel, J.C., Comfort properties and dyeing behaviour of cotton/milkweed blended rotor yarn fabrics, In: Indian Journal of Fibre \& Textile Research, 2017, 42, 1, 25-30

[5] Yang, R.H., Xue, Y., Gao, W.D., Structure and performance of color blended rotor spun yarn produced by a novel frame with asynchronous feed rollers, In: Textile Research Journal, 1-13, http://doi.org/10.1177/0040517517748493

[6] Lshtiaque, S.M., Study of cross section of yarn, In: Textile Asia, 1993, 11, 36-38

[7] Hearle, J.W.S., Goswami, P., Migration of fibers in yarns, part VII: further experiments on continuous filament yarns, In: Textile Research Journal,1968, 38, 8, 790-802

[8] Hamilton, J.B., Cooper, D.N.E., The radical distribution of fibers in blended yarns. Part II - Factors affecting the preferential migration of components in blended, In: Journal of Textile Institute Transactions, 1958, 49, 12, 687-698

[9] Sinha, S.K., Kumar, P., Ghosh, S., A study on the packing density of structurally modified ring spun yarn, In: Fibers \& Polymer, 2016, 17, 11, 1898-1907

[10] Lam, N.Y.K., Zhang, M., Guo, H., Effect of fiber length and blending method on the tensile properties of ring spun chitosan-cotton blend yarns, In: Textile Research Journal, 2017, 7, 2, 244-257

[11] Bechir, W., Mohamed, B.H., Bechir, A., Industrial cotton waste: recycling, reclaimed fiber behavior and quality prediction of its blend, In: Tekstilve Konfeksiyon, 2018, 28, 1, 14-20

[12] Uyanik, S., Baykal, P.D., Effects of fiber types and blend ratios on Murata Vortex yarn properties, In: Journal of the Textile Institute, 2018, 109, 8, 1099-1109

Authors:

RUI HUA YANG, QIAN QIAN DENG, CHUN PING XIE, WEI DONG GAO

Key Laboratory of Science \& Technology for Eco-Textiles, Education Ministry, Jiangnan University, 1800 Lihu Avenue, Wuxi, Jiangsu Province, 214122, P.R. China

Corresponding author:

RUI HUA YANG

e-mail: yangrh@jiangnan.edu.cn 